\title{
Ultrasound findings in aneuploidy fetusus: Evaluation of 332 cases
}

\section{Anöploidisi olan fetüslerin ultrasonografi bulguları: 332 vakanın değerlendirilmesi}

\author{
Ahmet Yalınkaya ${ }^{1}$, Ali İrfan Güzel ${ }^{1}$, Kadir Kangal ${ }^{1}$, Ayşegül Türkylmaz ${ }^{2}$, Zelal Savaş ${ }^{1}$ \\ ' Department of Obstetrics and Gynecology, School of Medicine, Dicle University, Diyarbakur, Turkey \\ ${ }^{2}$ Department of Medical Biology and Genetics, School of Medicine, Dicle University, Diyarbakur, Turkey
}

\section{Abstract}

Objective: To evaluate the ultrasound findings found on ultrasound examination among cases that had aneuploidy at amniocentesis.

Material and Methods: This prospective study was performed at Dicle University, School of Medicine, Department of Obstetrics and Gynecology. 332 cases applied to our department for prenatal diagnosis and amniocentesis (AC) was performed. Of these cases, twenty were found to have aneuploidy evaluated. The factors recorded were; mean age, gestational weeks, AC indications, ultrasound findings (by Toshiba 140A and GE Voluson 730 Pro 4D ultrasound device) and fetal anomalies.

Results: 332 cases have had AC by an experienced specialist, in a two year period. The mean age of the cases was $32.20 \pm 6.03$ years (22-44), and gestational weeks $16.45 \pm 1.46$ (13-19). AC indications were; high double and/or triple test with ultrasound findings and abnormal ultrasound findings. In $8(2.40 \%)$ cases there was no reproduction on cell culture. In 14 (4.21\%) cases, different types of chromosomal anomalies were detected. In these cases, peripheral blood was taken from the parents and if, at least in one of them this situation was present, this would be accepted as normal. In 20 (6.02\%) cases aneuploidy (numerical chromosomal anomalies) were detected and 11 of them (55.00\%) were trisomy 21. In all of these aneuploidy cases, different types of ultrasound findings were detected; most of them had multiple ultrasound findings, and some of them had one anomaly. Of all 20 aneuploidy cases; termination of pregnancy was decided in 17 (85\%) of them. $3(15 \%)$ of these cases decided to carry on their pregnancy. Of the 3 cases; one baby was delivered spontaneously and live, one had died in utero and labor was induced and the third pregnancy is ongoing.

Conclusion: The importance of ultrasound in fetal anomaly screening is incontrovertible and positive ultrasound findings are the most important indications of amniocentesis. For this reason, before amniocentesis, we advise a detailed ultrasound examination by an experienced specialist. (J Turkish-German Gynecol Assoc 2010; 11: 145-8)

Key words: Amniocentesis, aneuploidy, ultrasound findings

Received: 1 March, 2010

Accepted: 3 August, 2010

\section{Introduction}

Aneuploidies are the most frequent chromosomal anomalies; the incidence was reported as 9 in 1000 live births (1). The most frequent methods used for diagnosing chromosomal abnormalities is karyotyping of fetal cells by invasive procedures such as chorionic villus sampling and amniocentesis (2). Down syndrome, among all aneuploidies, is the most commonly
Özet

Amaç: Amniyosentez ile anöploidi tanısını almış olan vakaların ultrasonografi bulgularının gözden geçirilmesi.

Gereç ve Yöntemler: Bu prospektif çalışma Dicle Üniversitesi Tıp fakültesi Kadın hastalıkalıı ve Doğum bölümünde gerçekleştirildi. Prenatal tanı ünitemize gelen ve amniyosentez yapılmış 332 vaka ele alındı. Bunlardan 20 vakada anöploidi saptandı. Yaş, gebelik haftası, amniyosentez endikasyonları, ultrason bulguları (Toshiba 140A and GE Voluson 730 Pro 4D ultrason cihazı ile) ve fetal anomaliler kaydedildi.

Bulgular: Bu 332 amniyosentez 2 yll süresince deneyimli bir hekim tarafından yapıldı. vakalın ortalama yaşı $32.20 \pm 6.03$ yll (22-44) ve gebelik haftaları 16.45 \pm 1.46 (13-19) idi. Amniyosentez endikasyonları; yüksek ikili ve/veya üçlü test ile pozitif ultrasonografi bulgulan idi. Sekiz (\%2.4) vakada kültürde hücre üretilemedi. Ondört vakada (\%4.2), değişik tip kromozom anomalileri saptandı. Bu vakalarda ebeveyynlerden periferik kan külütrü yapıldı ve en az birinde bu varsa bu durum normal olarak değerlendirilid. Yirmi (\%6.0) vakada anöploidi saptandı. Bunların 11 tanesi ise (\%55.0) trizomi 21 idi. Tüm bu anöploidi vakalarında değişik ultrason bulgulan tespit edilmişti. bu vakaların 17 tanesi /\%85) terminasyonu kabul etti, 3 (\%15) tanesi ise gebeliğin devamına karar verdi. Bu gebeliklerin ikisi doğum ile sonland, bir bebek yaşıyor diğeri ise kaybedildi.

Sonuç: Fetal anomali taramasında ultrasonografinin rolu tartışılmazdir ve pozitif ultrason bulgusu amniyosentezin en önemli endikasyonlarını oluşturur. Bu nedenle amniyosentez öncesi deneyimli bir uzman tarafından detaylı ultrason incelemesini öneriyoruz.

(J Turkish-German Gynecol Assoc 2010; 11: 145-8)

Anahtar kelimeler: Amniyosentez, anöploidi, ultrason bulguları

Geliş Tarihi: 01 Mart 2010

Kabul Tarihi: 03 Ağustos 2010

encountered chromosomal abnormality in newborns, with an incidence of 1 in 800 live births. Because of decreased mentality and congenital heart disease, Down syndrome, therefore, has a substantial socioeconomic impact $(3,4)$. With a detailed ultrasound examination by an experienced specialist before invasive prenatal testing, many fetal anomalies may be detected. Therefore, this analysis is called genetic sonography (5). 
The aim of this study was to evaluate the findings detected on ultrasound examination for prenatal diagnosis in the cases where amniocentesis was performed.

\section{Material and Methods}

This prospective study was performed on 332 cases who applied to our department for prenatal diagnosis and amniocentesis (AC), the findings of 20 cases having aneuploidy evaluated, from January 2007 to December 2008, at Dicle University, School of Medicine, Department of Obstetrics and Gynecology. This is a reference hospital in the South Eastern region of Turkey. Most of the patients applying to our department have a lower socioeconomic status and the ratio of interrelative marriages is higher than the other regions of Turkey.

The factors recorded were; mean age, gestational weeks, gravidy and parity of the cases. The ultrasound examination and invasive testing were made by a single experienced specialist. The ultrasound findings were recorded on the amniocentesis form.

Indication for amniocentesis, ultrasound findings, fetal anomalies, karyotype results and treatments were also evaluated. The genetic sonogram was made by our Genetic Department after the AC.

\section{Results}

During the study period, 332 cases that had AC for prenatal diagnosis by an experienced specialist were included in the present study. The mean age of the cases was $32.20 \pm 6.03$ years $(22-44)$ and gestational weeks $16.45 \pm 1.46$ (13-19). AC indications were; high double $(n=5,25 \%)$ or triple test $(n=4,20 \%)$ with ultrasound findings and abnormal ultrasound findings $(n=8,40)$ (Table 1). In $8(2.40 \%)$ cases, there was no reproduction on cell culture. In $14(4.21 \%)$ cases, different types of chromosomal anomalies were detected. In these cases, peripheral blood was taken from the parents and if, at least in one of them this situation was present, this would be accepted as normal. In 20 (6.02\%) cases aneuploidy (numerical chromosomal anomalies) was detected and 11 of them (55.00\%) were trisomy 21 (Figure 1).

In all of the aneuploidy cases, different types of ultrasound findings were detected; most of them had multiple ultrasound findings, and some had one anomaly. Of all 20 aneuploidy cases; ,termination of pregnancy were decided in 17 (85\%) of them, $3(15 \%)$ of these cases decided to carry on with their pregnancy. Of the 3 cases; one baby was delivered spontaneously and live, one died in utero and labor was induced and one pregnancy is still ongoing (Table 2).

\section{Discussion}

Prenatal diagnosis for fetal aneuploidy began in the 1960's only considering the mother age (5). Later, the American College of Obstetricians and Gynecologists (ACOG) advised prenatal screening for cases 35 years and over (6). With only an advanced maternal age indication only $30 \%$ of the Down

Table 1. Demographic characteristics and amniocentesis indications of the aneuploidy cases

\begin{tabular}{|c|c|c|c|c|c|c|c|}
\hline Age & Karyotype & $\mathbf{G}$ & $\mathbf{P}$ & A & $\mathbf{Y}$ & GW & Amniocentesis Indication \\
\hline 29 & Klinefelter & 3 & 2 & 0 & 2 & 17 & Ultrasound findings \\
\hline 28 & Triploidy & 1 & 0 & 0 & 0 & 15 & Ultrasound findings, high triple test \\
\hline 41 & Trisomy 13 & 14 & 11 & 2 & 10 & 17 & Ultrasound findings, maternal age \\
\hline 34 & Trisomy 13 & 4 & 2 & 1 & 2 & 17 & Ultrasound findings, high double test \\
\hline 37 & Trisomy 18 & 8 & 7 & 0 & 7 & 16 & Ultrasound findings \\
\hline 25 & Trisomy 18 & 3 & 2 & 0 & 1 & 17 & Ultrasound findings \\
\hline 27 & Trisomy 21 & 2 & 1 & 0 & 1 & 16 & Ultrasound findings, high triple test \\
\hline 32 & Trisomy 21 & 2 & 1 & 0 & 1 & 17 & Ultrasound findings, high double test \\
\hline 35 & Trisomy 21 & 2 & 1 & 0 & 1 & 16 & Ultrasound findings, high double test \\
\hline 38 & Trisomy 21 & 4 & 3 & 0 & 3 & 16 & Ultrasound findings, hightriple test \\
\hline 37 & Trisomy 21 & 5 & 3 & 1 & 3 & 13 & Ultrasound findings \\
\hline 35 & Trisomy 21 & 5 & 3 & 1 & 3 & 17 & Ultrasound findings \\
\hline 39 & Trisomy 21 & 4 & 3 & 0 & 3 & 18 & Ultrasound findings, maternal age \\
\hline 31 & Trisomy 21 & 1 & 0 & 0 & 0 & 17 & Ultrasound findings, high double test \\
\hline 32 & Trisomy 21 & 2 & 1 & 0 & 1 & 17 & Ultrasound findings, high double test \\
\hline 44 & Trisomy 21 & 4 & 2 & 1 & 2 & 17 & Ultrasound findings, maternal age \\
\hline 26 & Trisomy 21 & 2 & 0 & 1 & 0 & 18 & Ultrasound findings, high triple test \\
\hline 22 & Turner & 2 & 1 & 0 & 0 & 16 & Ultrasound findings \\
\hline 25 & Turner & 1 & 0 & 0 & 0 & 19 & Ultrasound findings \\
\hline 27 & Turner & 1 & 0 & 0 & 0 & 13 & Ultrasound findings \\
\hline
\end{tabular}


Table 2. Ultrasound findings and prognosis of $\mathbf{2 0}$ aneuploidy cases

\begin{tabular}{|c|c|c|}
\hline Karyotype & Ultrasound Findings & Prognosis \\
\hline Klinefelter & Oligohydramnios, hyperecogenic bowel & Termination \\
\hline Triploidy & CCA, ventriculomegaly, symmetric IUGR & Termination \\
\hline Trizomy 13 & $\begin{array}{l}\text { Echogenic focus in the heart, VSD, hydrocephaly, CCA, talipes, omphalocele, spina bifida, } \\
\text { dilated right heart }\end{array}$ & Termination \\
\hline Trisomy 13 & VSD, pistol shot on hand, left CPC, cryptorchidism & Termination \\
\hline Trisomy 18 & Cystic hygroma, omphalocele & Termination \\
\hline Trisomy 18 & Calvarium offication defect, hypodensity in all bones, dysplasia of skeleton, achondroplasia & Termination \\
\hline Trisomy 21 & Thick NT, aplasic NB, short extremities & Living \\
\hline Trisomy 21 & Hypoplasic NB, Echogenic focus in the heart & Termination \\
\hline Trisomy 21 & Bilateral CPC, short extremites & Termination \\
\hline Trisomy 21 & Cystic hygroma, hyperecogenic bowel & Termination \\
\hline Trisomy 21 & Anasarca edema, hyperecogenic bowel, cystic hygroma & Termination \\
\hline Trisomy 21 & Cystic hygroma, Anasarca edema, bilateral pyelectasia, aplasic NB & Termination \\
\hline Trisomy 21 & Short extremites, VSD & IUMF \\
\hline Trisomy 21 & Thick NT, aplasic NB, short extremites & Termination \\
\hline Trisomy 21 & Hyperecogenic bowel, Echogenic focus in the heart, Thick NF, hypoplasic NB & Termination \\
\hline Trisomy 21 & Hyperecogenic bowel, left CPC, bilateral pylectasia, thick NF hypoplasic NB, Face angel : $95^{\circ}$ & Termination \\
\hline Trisomy 21 & Hypoplasic NB, Thick NF, Face angel $101^{\circ}$ & Pregnancy going on \\
\hline Turner & Cystic hygroma & Termination \\
\hline Turner & Cystic hygroma, short extremities & Termination \\
\hline Turner & Cystic hygroma & Termination \\
\hline
\end{tabular}

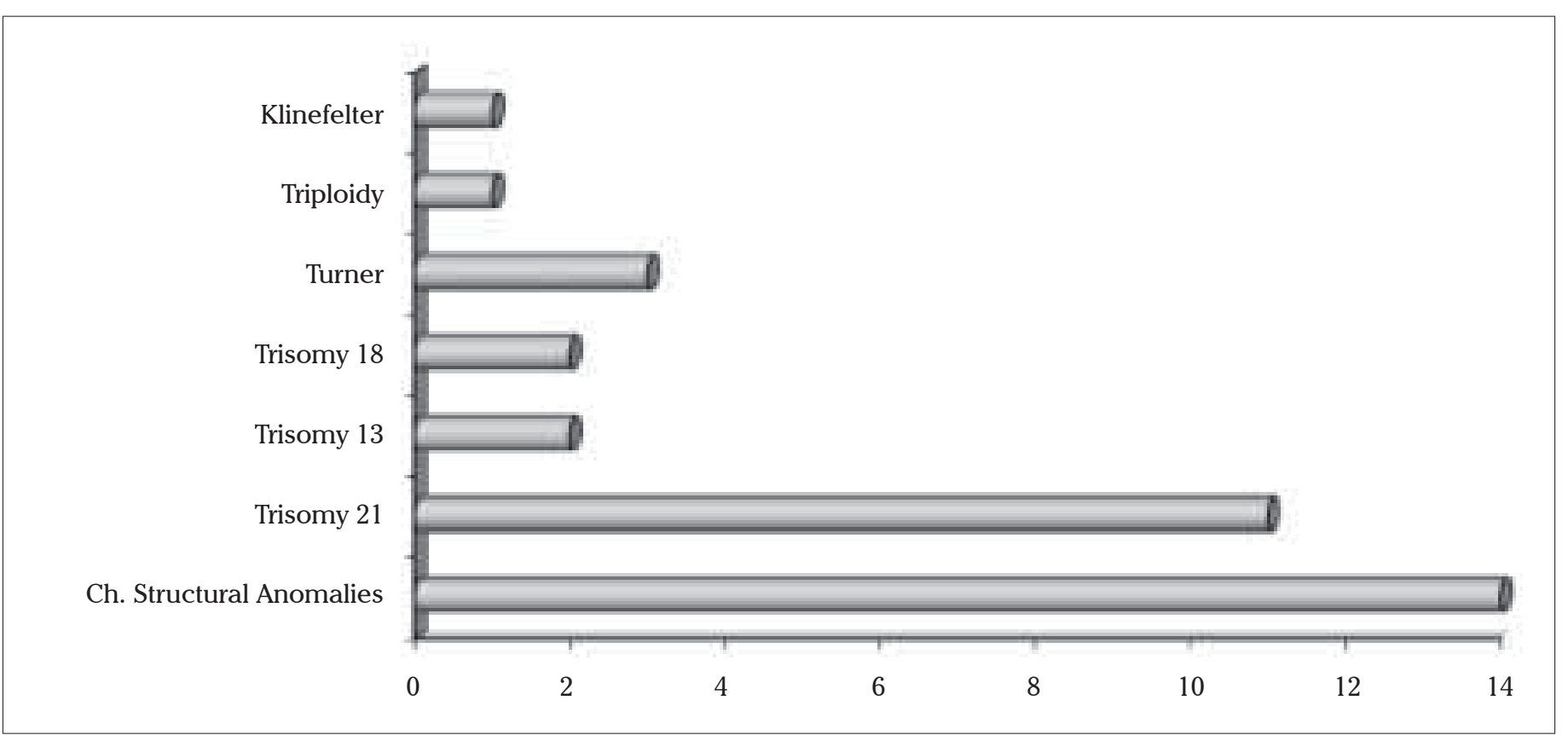

Figure 1. The cases that structural and numerical chromosomal anomailes detected on amniocentesis 
syndromes can be detected (7). Hence, this indication lost its importance.

Nowadays, the main indications are advanced maternal age, biochemical tests and positive ultrasound findings (6). The importance of ultrasound examination also named genetic sonography, has been reported in many studies. The main indication of genetic sonographic examination is the detection of fetal anomalies $(8,9)$. The risk of fetal aneuploidy increases with the detection of soft markers. The risk increases more with the number of the soft markers $(10,11)$.

Genetic sonogram has some difficulties such as maternal obesity. Tsai et al. reported in their study that the detection rates of abnormalities on ultrasound screening related inversely with maternal obesity (12)

Nyberg et al. reported that most soft markers in aneuploidy cases were hyperecogenic bowel, ventriculomegaly and cardiovascular system malformations (13). In most of our cases the anomalies were similar to Nyberg's study (Table 2). Of our 20 aneuploidy cases, 7 (14\%) were over 35 years age, and advanced maternal age was an amniocentesis indication in only $3(6 \%)$ of them. Chelli et al found that first trimester ultrasound screening may allow early detection of a large number of aneuploidies and fetal malformations (13). In 9 (18\%) of the cases, the indication was a high double or triple test. However, in all of the 20 cases, there were ultrasound findings. We consider that this higher ratio of our study is related to higher frequency of the intermarriages and the experience of the specialist who performed the prenatal diagnosis.

In conclusion, nowadays, the importance of ultrasound in fetal anomaly screening is incontrovertible and positive ultrasound findings are the most important indications of amniocentesis. For this reason, before amniocentesis we advise detailed ultrasound examination by an experienced specialist.

\section{Conflict of interest}

No conflict of interest is declared by authors.

\section{References}

1. Cunningham F, Hauth J, Leveno K, Gilstrap L, Bloom S, Wenstrom K (edts). Genetics. Williams Obstetrics., Twenty Second Edition. McGraw- Hill Companies. New York, USA. 2005. P.285-312.

2. ACOG Practice Bulletin No. 88, December 2007. Invasive prenatal testing for aneuploidy.. Obstet Gynecol 2007; 110: 1459-67.

3. Spencer K, Souter V, Tul N, Snijders R, Nicolaides KH. A screening program for trisomy 21 at 10-14 weeks using fetal nuchal translucency, maternal serum free beta-human chorionic gonadotropin and pregnancy-associated plasma protein-A. Ultrasound Obstet Gynecol 1999; 13: 231-7.

4. Wald NJ, Hackshaw AK. Combining ultrasound and biochemistry in first-trimester screening for Down's syndrome. Prenat Diagn 1997; 17: 821-9.

5. Summers AM, Langlois S, Wyatt P, Wilson RD; Society of Obstetricians and Gynaecologists of Canada.Prenatal screening for fetal aneuploidy. J Obstet Gynaecol Can. 2007; 29: 146-79.

6. ACOG Practice Bulletin No. 88, December 2007. Invasive prenatal testing for aneuploidy. Obstet Gynecol 2007; 110: 1459-67.

7. Kocun CC, Harrigan JT, Canterino JC. Changing trends in patient. decisions concerning genetic amniocetesis. Am J Obstet Gynecol, $2000 ; 182 ; 1018-20$.

8. Saari-Kemppainen A, Karjalainen O, Ylostalo P, Heinonen OP. Ultrasound screening and perinatal mortality: controlled trial on systematic one-stage screening in pregnancy. The Helsinki Ultrasound Trial. Lancet 1990; 336: 387-91.

9. Long G, Sprigg A. A comparative study of routine versus selective fetal anomaly ultrasound scanning. J Med Screen 1998; 5: 6-10.

10. Nicolaides KH, Snijders RJ, Gosden CM, Berry C, Campbell S. Ultrasonographically detectable markers of fetal aneuploidy. Lancet 1992; 340: 704-7.

11. Bromley B, Lieberman E, Shipp TD, Benacerraf BR. The genetic sonogram: a method of risk assessment for Down syndrome in the second trimester. J Ultrasound Med 2002; 21: 1087-96.

12. Tsai LJ, Ho M, Pressman EK, Thornburg LL. Ultrasound screening for fetal aneuploidy using soft markers in the overweight and obese gravida. Prenat Diagn. 2010 Jun 24. [Epub ahead of print].

13. Chelli D, Gaddour I, Najar I, Boudaya F, Zouaoui B, Sfar E, et al. First trimester ultrasound: an early screening tool for fetal structural and chromosomal abnormalities. Tunis Med. 2009; 87: 857-62.

14. Nyberg DA, Resta RG, Luthy DA, Hickok DE, Mahony BS, Hirsch $\mathrm{JH}$. Prenatal sonographic findings of Down syndrome: review of 94 cases. Obstet Gynecol. 1990; 76: 370-7. 